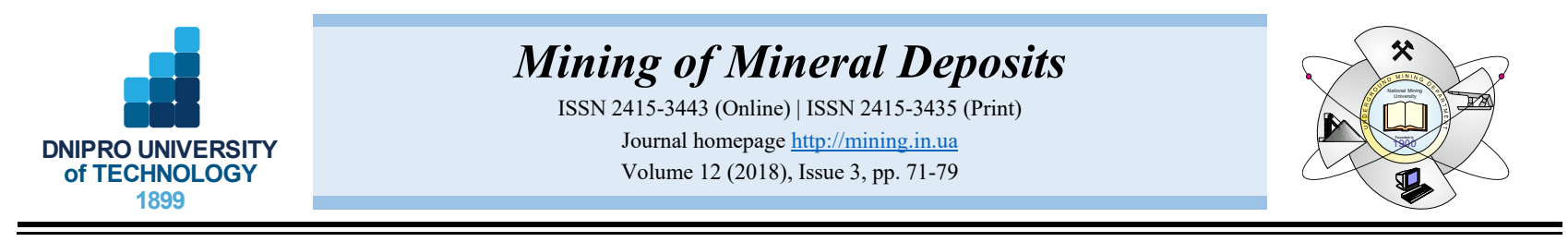

UDC 504.054:622.23.05

https://doi.org/10.15407/mining12.03.071

\title{
WAYS TO IMPROVE SAFETY OF A PUMPING-CIRCULATORY SYSTEM OF A DRILLING RIG
}

\author{
L. Skitsa ${ }^{1}$, T. Yatsyshyn ${ }^{1 *}$, M. Liakh ${ }^{1}$, O. Sydorenko ${ }^{2}$ \\ ${ }^{I}$ Ivano-Frankivsk National Technical University of Oil and Gas, Ivano-Frankivsk, Ukraine \\ ${ }^{2}$ Scientific-Research and Design Institute PJSC "Ukrnafta", Ivano-Frankivsk, Ukraine \\ *Corresponding author: e-mail yatsyshyn.t@gmail.com, tel. +380509336851, fax: +380342547139
}

\begin{abstract}
Purpose. To modernize a pumping-circulatory system of a drilling rig in order to improve the environmental safety data, reliability, and convenience during oil well construction.

Methods. Methods of system analysis of the conditions and use of different design features of facilities and equipment of pumping-circulatory systems for well washing with muds have been applied. Computer modeling has been performed to assess the risks of pumping-circulatory station operation; theoretical and experimental data have been evaluated and generalized to develop environmentally friendly pumping-circulatory system.

Findings. Improved design of a pumping-circulatory system which components are made of elastic (e.g. rubbertextile) materials has been proposed; the design provides air-tightness and prevents harmful substances from penetrating into the environment. Modernized pumping-circulatory system allows obtaining efficient operation results since it meets following requirements: quick readjustment to the drilling mode under certain conditions; minimum time for transportation to the operating site, assembling and disassembling; compactness and mobility; convenient and safe labor conditions for the personnel; and considerable damage-resistance.
\end{abstract}

Originality. The paper demonstrates the approach aimed at the increase of environmental safety level, labor protection, and efficiency of operating processes in terms of pumping-circulatory system based on stage-by-stage study of different sections of the equipment, technological processes, and impact of the related substances. The research has made it possible to determine the ways for the improvement of separate equipment units as well as to define their positioning and provide proper operation modes. That approach, aimed at the increase of the environmental safety level of the industry, is appropriate to be applied at other stages of the life cycle of oil and gas industry.

Practical implications. The pumping-circulatory system under consideration requires minimum transportation expenses being very cheap to transport, assemble, operate, maintain, and disassemble.

Keywords: pumping-circulatory system, environmental safety, oil and gas wells, well construction, rubber-textile reservoirs, mud

\section{INTRODUCTION}

Oil and gas industry is quite often associated with penetration of harmful substances into the environment. While drilling oil and gas wells in the process of washing the well with the mud, certain conditions are formed resulting in the intensive penetration of oil products and chemical reagents of different hazard class into the environment.

The mud may contain sodium hydroxide $(\mathrm{NaOH})$, sodium carbonate $\left(\mathrm{Na}_{2} \mathrm{CO}_{3}\right)$, soldering acid $(\mathrm{HCl})$, hydrogen disulfide $\left(\mathrm{H}_{2} \mathrm{~S}\right)$ etc. that are harmful both for human health and the environment.

There are many scientific papers concerning the environmental impact of oil and gas complex, especially the process of well construction. The authors (Kurhanskyi, 2006; Podavalov, 2010) define the sources of negative environmental impact of a well construction process upon different environmental components (soils, atmospheric air, water medium, flora and fauna), in particular the effect made by the components of muds. However, the researchers do not offer particular technical solutions in order to prevent negative environmental impact.

The available designs of pumping-circulatory systems and their separate components are studied in various papers (Arakelyan, Lyskova, \& Korchakov, 1997; Fedorovych, Kryzhanivskyi, Korop, \& Liakh, 2008; Savyk et al., 2009; Shvydkyi, 2010; Steinsvag, Galea, Krüger, \& Peikli, 2011; Shkitsa, Yatsyshyn, Popov, \& Artemchuk,

(C) 2018. L. Skitsa, T. Yatsyshyn, M. Liakh, O. Sydorenko. Published by the Dnipro University of Technology on behalf of Mining of Mineral Deposits. This is an Open Access article distributed under the terms of the Creative Commons Attribution License (http://creativecommons.org/licenses/by/4.0/), which permits unrestricted reuse, distribution, and reproduction in any medium, provided the original work is properly cited. 
2013). Some papers (Steinsvag, Galea, Krüger, \& Peikli, 2011; Shkitsa, Yatsyshyn, Popov, \& Artemchuk, 2013) consider negative impact of the vapour generated in the process of primary mud cleaning on a mud screen. Certain technical measures of mud temperature control to prevent intensive vapour generation on a mud screen have been proposed; however, the design itself remains unchanged, and its open surface continues to be the source of hazardous substances penetration into the environment (Steinsvag, Galea, Krüger, \& Peikli, 2011).

We know about pumping-circulatory stations (Arakelyan, Lyskova, \& Korchakov, 1997; Savyk et al., 2009) consisting of the tanks for special purposes, intake and discharge lines, mud pumps, cleaning unit, and isolation valves. Main disadvantages of these systems are as follows:

- all the tanks are not air-tight, i.e. they are open; the mud (flushing water), saturated with harmful, dangerous for health substances, evaporates; that evaporation is more intensive when the mud comes out of the well at high temperature;

- it is very difficult to transport as well as to assemble and disassemble large-sized and heavy-metal tanks.

Pumping-circulatory system of a drilling rig (Fedorovych, Kryzhanivskyi, Korop, \& Liakh, 2008) has tanks and reservoirs made of rubbertextile material, cleaning unit, mud pumps, intake and discharge lines, standpipe, and isolation valves. Disadvantage of the system is in the fact that it is not designed to complete all technological processes due to different conditions that may occur while drilling and does not make it possible to prepare quickly the muds with certain parameters, necessary for high-quality and accident-free borehole drilling.

The paper proposes a scheme of air-tight pumpingcirculatory system (Shvydkyi, 2010) that may serve as the basis for further adjustment to certain drilling conditions; nevertheless, it does not take into account the connection of a unit for flush water preparation, air-tightness, and piping of tanks with chemical reagents for mud processing into a joint system. Making up of the well is not provided in the process of trip out of hole operation.

The available pumping-circulatory systems have mud-storing tanks being large-sized, difficult to handle, assemble, and transport. The problem of preventing mud evaporation is still unsolved as well as the issue to reduce evaporations containing hazardous substances at different sections of a pumping-circulatory system during different technological operations. The known circulatory systems provoke intensive penetration of polluting substances into the environment; they do not ensure the necessary level of environmental safety as the majority of mud-storing tanks are often open for influence of various external factors. That is why the considered pumping-circulatory systems may be treated as the ones not ensuring the necessary level of environmental safety as well as the quality of oil and gas wells drilling.

Thus, there arises the need to design a modernized circulatory system which will make it possible to carry out flushing processes effectively at the well and will ensure the required air-tightness of the main components in order to increase the environmental safety of oil and gas wells drilling.

\section{STUDY OF ENVIRONMENTAL SAFETY LEVEL OF A PUMPING-CIRCULATORY SYSTEM OF A DRILLING RIG}

Improvement of the environmental safety of the available pumping-circulatory systems needs thorough studies of both equipment and technological processes being closely connected with mud circulation. That will make it possible to outline the main factors effecting the level of environmental safety of a pumping-circulatory system and define environmental risks during the system operation.

\subsection{Defining the factors effecting the level of environmental safety of a pumping-circulatory system}

Pumping-circulatory system of drilling rigs, as it has been mentioned before, is mainly open (Fig. 1). The mud circulates there together with different hazardous substances; some of them are used to improve technological processes: 55\% - gel powder, chalk, barytes; $16 \%$ - acids; $11 \%$-surface-active substances; $7 \%$ - water-soluble salts, polymers $-5 \%$, dissolvent $-4 \%$, caustic and different chemical reagents 1\% each (Podavalov, 2010).

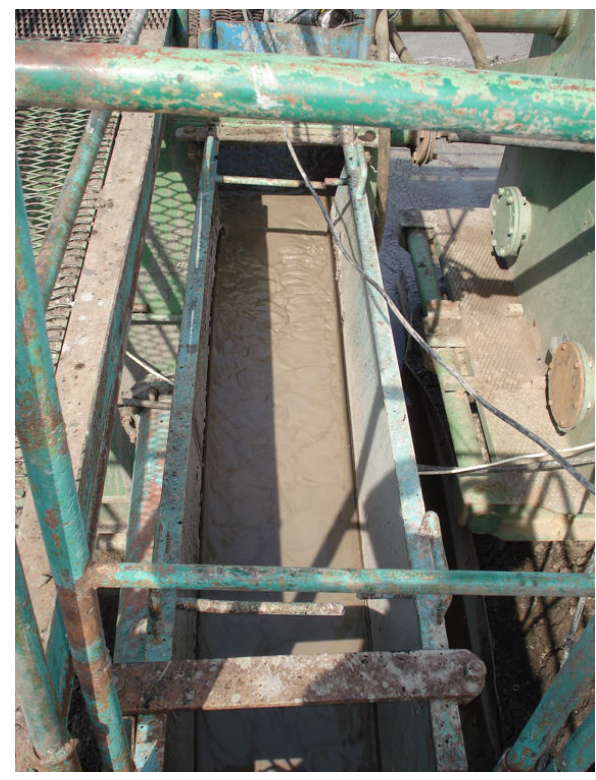

Figure 1. Unsealed channels of a pumping-circulatory system

Hazardous substances may be generated in the process of mud circulation and its contact with drilled-out layers, saturated with hydrogen disulfide or other dangerous substances.

Apart from direct spills, the environment is constantly polluted due to evaporations. Thus, the paper (Shkitsa, Yatsyshyn, Popov, \& Artemchuk, 2013) notes substantial negative impact of channel system evaporations. That is why it is necessary to study the factors promoting vapor formation during mud circulation.

Evaporation of the fluid from a free surface is caused by thermal movement of the fluid molecules and depends on its intensity: the faster molecules move, the faster evaporation is. The mud comes out of the well heated up to high temperatures.

Main conditions affecting the evaporation process are: chemical properties, temperature, disengagement area, duration of evaporation, and air velocity. 
Intensity of evaporation of $i^{\text {th }}$ component of the fluid during laminar flow of the external medium air at the surface of evaporation is defined by following formula (Yatsyshyn, 2012):

$G_{i}=11.4 \cdot 10^{-4} S L^{-\frac{1}{4}} D_{i}^{\frac{1}{2}}\left(p_{f l}-p_{0}\right)^{\frac{5}{4}} M_{i}^{\frac{5}{4}}\left(\frac{M_{\text {o.e. }}}{M_{i}}-1\right)^{\frac{1}{4}} \frac{k_{2}}{k_{1}},(1)$

where:

$G$ - amount of evaporated substance, $(\mathrm{g} / \mathrm{h}) ;$

$S$ - area of evaporation, $\left(\mathrm{m}^{2}\right)$;

$L$ - typical size, $(\mathrm{m})$, for round surface $-L=d$, for square surface $-L=a$, in terms of rectangular and iregular-shape surface $-L=\sqrt{d}$;

$M_{\text {o.e. }}-$ molecular weight of the external medium vapors;

$M_{i}-$ molecular weight of vapors of the substance being determined;

$p_{f l}$ and $p_{0}$ - partial pressure of vapors above the surface and in the external medium, $(\mathrm{Pa})$;

$k_{1}$-coefficient that considers the lowering of evaporation surface temperature;

$k_{2}$ - coefficient that considers the degree of evaporation surface closure;

$D_{i}-$ coefficient of fluid vapors diffusion, $\left(\mathrm{cm}^{2} / \mathrm{s}\right)$.

During turbulent air motion near the evaporation surface, the amount of hazardous substances penetration into the atmosphere from the fluid surface is calculated according to following formula:

$$
G_{i}=3.0 \cdot 10^{-4} S D_{i}^{\frac{1}{3}}\left(p_{f l}-p_{0}\right) \frac{4}{3} M_{i}^{\frac{4}{3}}\left(\frac{M_{\text {o.e. }}}{M_{i}}-1\right)^{\frac{1}{3}} \frac{k_{2}}{k_{1}} .
$$

Regulations on fire safety contain following formula to calculate mass of the fluid that evaporates from the open spill surface indoors:

$m_{B}=10^{-6} \eta p_{s . v .} S \tau \sqrt{M}$,

where: $\eta$-coefficient depending on the velocity and the temperature of air flow above the surface of evaporation (defined by a corresponding table);

$M$-molar weight of the evaporating substance $(\mathrm{kg} / \mathrm{mole})$;

$p_{\text {s.v. }}-$ pressure of the saturated vapor at the temperature of evaporation, $(\mathrm{mmHg})$.

Values of partial pressures and concentrations of hazardous gases and vapours in the atmosphere should be taken in terms of the fluid surface temperature. During stationary mode, that temperature is defined according to the heat balance: the heat incoming to the fluid from the outside, the heat being given and accepted by the air and the fluid as a result as their heat exchange, and the heat spent on evaporation (Tishchenko, 1991).

Analysis of equation $(1-3)$ has taken into account all the above-mentioned industrial conditions involving the process of evaporation. As a result, the factors have been established that are necessary to be taken into consideration while modernizing pumping-circulatory system in order to decrease emissions of hazardous substances into the atmosphere (Table 1).

Values of the parameters of separate equipment units associated with the factors of high evaporation level have been demonstrated in terms of IDECO-525 drilling rig; moreover, possible tendencies of the performance improvement have been shown.

\subsection{Assessment of environmental risks during the operation of a pumping- circulatory system of a drilling rig}

Penetration of hazardous substances into the lowest atmospheric layers during different technological processes and industrial operations while oil and gas wells drilling has been studied by means of specially designed computer software complex (Shkitsa \& Yatsyshyn, 2013). Environmental risks during different technological operations involving different equipment have been calculated. Values of the risks have been calculated according to (Alymov \& Tarasova, 2004) as well as according to current regulations of the Ministry of Health of Ukraine (MOZ, 2007).

Table 1. Factors that should be taken into account during pumping-circulatory system modernization

\begin{tabular}{|c|c|c|c|c|c|}
\hline \multirow[b]{2}{*}{ No. } & \multirow[b]{2}{*}{ Factor } & \multicolumn{3}{|c|}{ Pumping-circulatory system equipment } & \multirow[b]{2}{*}{ Measures of modernization } \\
\hline & & $\begin{array}{c}\text { Mud } \\
\text { screens }\end{array}$ & $\begin{array}{l}\text { Channel } \\
\text { system }\end{array}$ & Reservoirs & \\
\hline 1 & Evaporation area, $S, \mathrm{~m}^{2}$ & 7.04 & 11 & 24.75 & Maximum air-tightness of all \\
\hline 2 & $\begin{array}{l}\text { Coefficient that considers cover } \\
\text { degree of the evaporating } \\
\text { surface } k_{2}\end{array}$ & 1 & 1 & 0.6 & $\begin{array}{l}\text { the parts of circulatory system } \\
\text { where the mud is available } \\
\text { (mud screens, channel system) }\end{array}$ \\
\hline 3 & $\begin{array}{l}\text { Coefficient depending on } \\
\text { velocity and temperature } \\
\text { of air flow above the surface } \\
\text { of evaporation, } \eta\end{array}$ & \multicolumn{3}{|c|}{$\begin{array}{l}\text { Depends on certain climate conditions } \\
\text { and defined according to table values }\end{array}$} & $\begin{array}{l}\text { Reduction of the effect of } \\
\text { external factors upon the cost } \\
\text { of the equipment air-tightness }\end{array}$ \\
\hline 4 & $\begin{array}{l}\text { Saturated vapor } \\
\text { pressure, } P_{\text {s.v. }}, \mathrm{mmHg}\end{array}$ & \multicolumn{3}{|c|}{$\begin{array}{c}\text { Depends on chemical properties of substances } \\
\text { and environmental temperature }\end{array}$} & $\begin{array}{l}\text { Creating conditions to generate } \\
\text { oversaturation pressure and to } \\
\text { limit evaporation }\end{array}$ \\
\hline
\end{tabular}

According to the methodology (Alymov \& Tarasova, 2004), the risks have been calculated with the use of threshold models and nonthreshold models. The models make it possible to estimate negative impact of technogenic air pollution during oil and gas wells construction, its effect on personnel's health and the population of nearby territories that may result in negative toxic effects and chronic diseases (including oncogenic and immunotoxic ones). Main conditions to model mud vapors dissipation are based on long-term studies and wind rose of the 
territory under analysis: east wind of $5 \mathrm{~m} / \mathrm{s}$ velocity; air temperature is $23-24^{\circ} \mathrm{C}$; air humidity is $45 \%$; air pressure is $741 \mathrm{mmHg}$; stratification of atmosphere - convection, stability class - B; without precipitations; the reagent under study is methane (Shkitsa \& Yatsyshyn, 2013).

To evaluate the risks of immediate toxic effects during air pollution of clear threshold character, a model of individual impact threshold is used; the model is as follows:

$R I_{z}=\frac{1}{\sqrt{2 \pi}} \int_{-\infty}^{a+b \lg \left(\frac{C}{M P C_{\text {o.t. }}}\right)} \exp \left(\frac{-\tau^{2}}{2}\right) d \tau$,

where:

$a, b$-parameters depending on toxicological properties of the substance. In our case, in terms of methane, belonging to category of hazard $4, a=-1.41 ; b=2.33$; and $C$ - concentration of toxicant in the air, $\mathrm{mg} / \mathrm{m}^{3}$.

To determine the risks of chronic intoxication, being measured within a certain period of time, following equation is used:

$$
R_{z}=1-\exp \left[-0.174\left(\frac{C}{M P C_{\text {d.a. }} K_{z}}\right)^{\beta} t\right] \text {, }
$$

where:

$\beta$-coefficient that considers peculiarities of toxic characteristics of the substance; in terms of methane $\beta=0.86$;

$K_{z}$ - parameter, depending on hazard category of the substance; in terms of methane $-K_{z}=3$;

$C$-concentration of pollutants in the atmosphere effecting during certain period of time $\mathrm{t}, \mathrm{mg} / \mathrm{m}^{3}$.

Values of $a, b, \beta$, and $K_{z}$ parameters depend on the substance hazard category (Table 2).

Table 2. Values of coefficients $a, b, \beta$, and $K_{z}$

\begin{tabular}{cccccc}
\hline $\begin{array}{c}\text { Substance } \\
\text { hazard } \\
\text { category }\end{array}$ & $\begin{array}{c}\text { Substance } \\
\text { characteristic }\end{array}$ & $a$ & $b$ & $\beta$ & $K_{z}$ \\
\hline $1^{\text {st }}$ & $\begin{array}{c}\text { Extremely } \\
\text { hazardous }\end{array}$ & -9.15 & 11.66 & 2.40 & 7.5 \\
\hline $2^{\text {nd }}$ & $\begin{array}{c}\text { Highly } \\
\text { hazardous }\end{array}$ & -5.51 & 7.49 & 1.31 & 6.0 \\
\hline $3^{\text {rd }}$ & $\begin{array}{c}\text { Moderately } \\
\text { hazardous }\end{array}$ & -2.35 & 3.73 & 1.00 & 4.5 \\
\hline $4^{\text {th }}$ & Low-hazardous & -1.41 & 2.33 & 0.86 & 3.0 \\
\hline
\end{tabular}

According to the methodology (MOZ, 2007), during inhalation substance intake, the calculation of hazard coefficient is done by formula (6):

$$
H Q_{i}=\frac{C_{i}}{R f C},
$$

where:

$H Q_{i}$ - hazard coefficient of the impact of $i^{\text {th }}$ substance, in our case it is methane;

$C_{i}$ - impact level of $i^{\text {th }}$ substance, $\mathrm{mg} / \mathrm{m}^{3}$;

$R f C$ - safe impact level of $\mathrm{CH}_{4}=50 \mathrm{mg} / \mathrm{m}^{3}$.

As a matter of convenience, the results of risks calculations have been represented in the form of characteris- tic curves (Figs. $2-4$ ). Figure 2 shows the dependence of chronic intoxication risk within the time period $t=10$ days by the methane vapors from the distance to pollution sources along the wind direction. The risk level of chronic intoxication due to air pollution depends on the time people spend within the polluted territory. Maximum risk values $R_{z}$ are observed during drilling tools round trips and at the mud availability in the channel system $\left(R_{z}=0.99\right)$. Value of chronic intoxication risk rises with the increase of the period spent under the influence of pollutants.

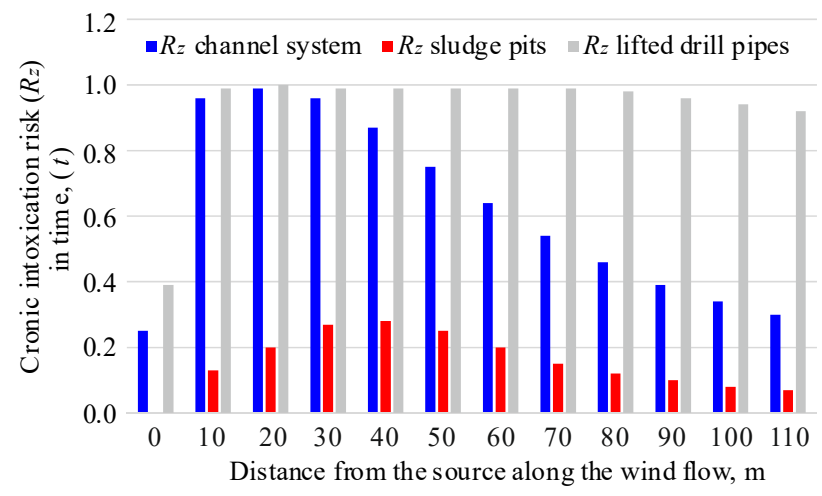

Figure 2. Dependence of chronic intoxication risk by the vapors of methane upon the distance to the sources along the wind direction

Under the given conditions, moderate risk of the immediate toxic effects for the substance under study (methane) is observed (Fig. 3).

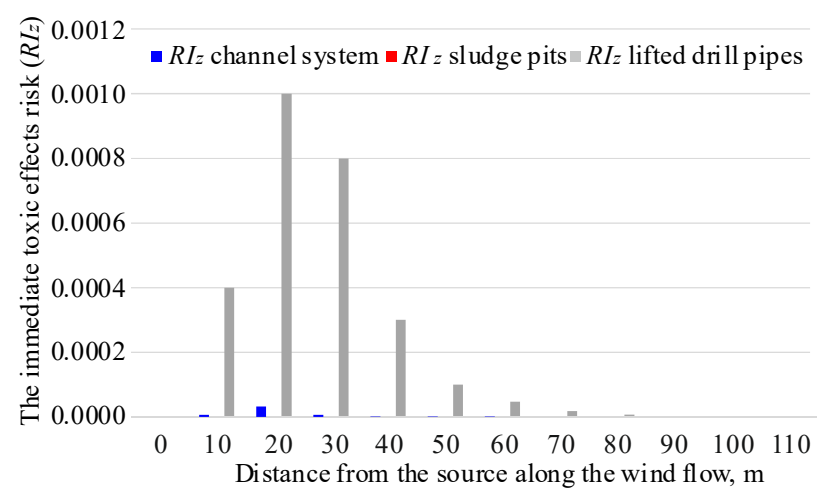

Figure 3. Dependence of risks of immediate toxic effects by the methane evaporations upon the distance to the sources along the wind flow

Characteristic curves (Fig. 4) show the values of hazard coefficient $\mathrm{HQ}_{\mathrm{NH} 4}$. According to the criteria characterizing hazard coefficient (Table 3 ), it is pointed out that $\mathrm{HQ}>1$ during drilling tools round trips and during mud circulation through a channel system.

It means that non-oncogenic risk for the personnel's health under the influence of methane from the mud evaporations at its concentration in the solution being $5 \%$ may not be treated as acceptable; there is a probability of harmful effects upon the drilling rig personnel.

The risk calculation results show that the most hazardous operations are drilling tools round trips. The chronic intoxication risk is 1 . 


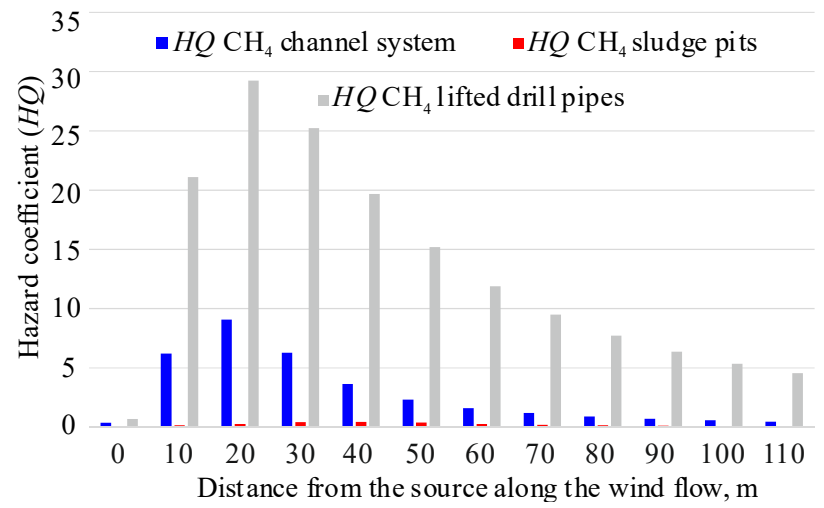

Figure 4. Dependence of hazard coefficient upon the distance to the source along the wind flow

Table 3. Oncogenic risk criteria

\begin{tabular}{clc}
\hline No. & \multicolumn{1}{c}{ Risk characteristic } & $\begin{array}{c}\text { Hazard } \\
\text { coefficient } \\
\text { (HQ) }\end{array}$ \\
\hline 1 & $\begin{array}{l}\text { Risk of possible negative effects } \\
\text { is treated as negligible }\end{array}$ & $<1$ \\
\hline 2 & $\begin{array}{l}\text { Boundary value that does not } \\
\text { require urgent measures but cannot } \\
\text { be treated as quite acceptable }\end{array}$ & 1 \\
\hline 3 & $\begin{array}{l}\text { Probability of hazardous effects } \\
\text { rises proportionally to the } \\
\text { increase of HQ }\end{array}$ & $>1$ \\
\hline
\end{tabular}

It is caused by the fact that during drill pipes lifting, the pollution happens due to the imperfection of the facilities for drilling tool cleaning. That is why technological processes during drilling tools round trip have been analyzed, and an engineering solution for a facility to clean drilling tool has been proposed (Shkitsa, Yatsyshyn, Lyakh, \& Sydorenko, 2016). The developed tool makes it possible to improve cleaning of tools with complicated surface geometry as well as to neutralize hazardous substances in the process of trip out of hole operation.

Pumping-circulatory system is the next facility to be considered as the one with high risk values. During technological operations while oil and gas wells constructing, a pumping-circulatory system that transports mud poses risks of hazardous substances penetration into the atmosphere. Thus, the paper proposes to have maximum airtightness for all the sections of a pumping-circulatory system, i.e. to modernize it.

\section{MODERNIZING PUMPING-CIRCULATORY SYSTEM OF A DRILLING RIG}

\subsection{Updating separate equipment units of a pumping-circulatory system}

Analysis of the factors influencing the environmental safety level and the risks defined during the operation of a pumping-circulatory system has made it possible to determine the equipment that requires updating to increase safety of its application, environmental compliance, and power saving.

Equipment of the available circulatory systems has been studied; the systems may be divided into following groups:

- facilities for mud preparation: hydraulic (mechanical) mud mixers, reservoirs;
- facilities for mud delivery into the well: supercharging pumps, delivery line, rotary swivel, drilling pipes;

- facilities for mud cleaning: mud screens, mud desilters, degassers.

In terms of mud cleaning facilities, attention should be paid to mud desilters, which are the first to receive the mud from the well. At this stage it is saturated with different substances according to the mud composition and the substances entering as the result of the contact with the drilled-out layers and the equipment; during the opening of gas horizons vapors may contain explosive materials. When it comes out of the well, the mud may have high temperature values that depend on its depth and the geothermal gradient (Shkitsa \& Yatsyshyn, 2012). Intensive movement of vibration frames intensifies evaporation of the heated mud (Fig. 5).

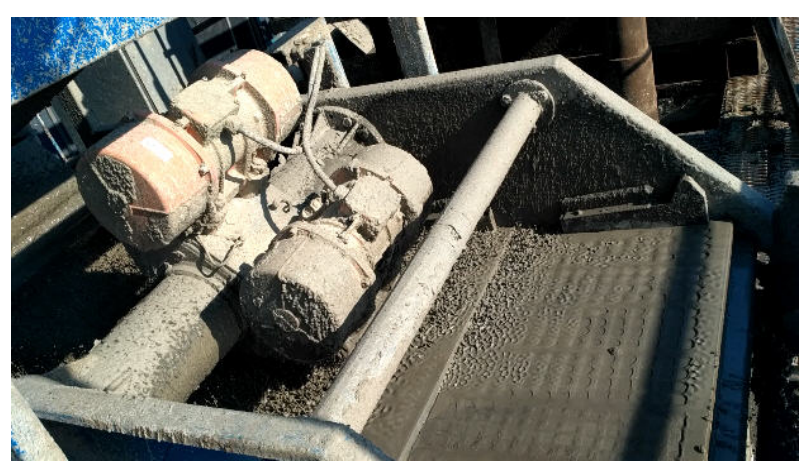

Figure 5. Mud screen in the operating mode

To solve the problem, a modernized mud screen with a protective shield has been designed (Fig. 6) (Shkitsa, Yatsyshyn, Liakh, \& Fedoliak, 2013).

That mud screen design to clean the mud will reduce evaporation and provide partial isolation of vapour at the expense of space concentration above the net. The structure may be equipped with special discharges to utilize hazardous gases and vapour.

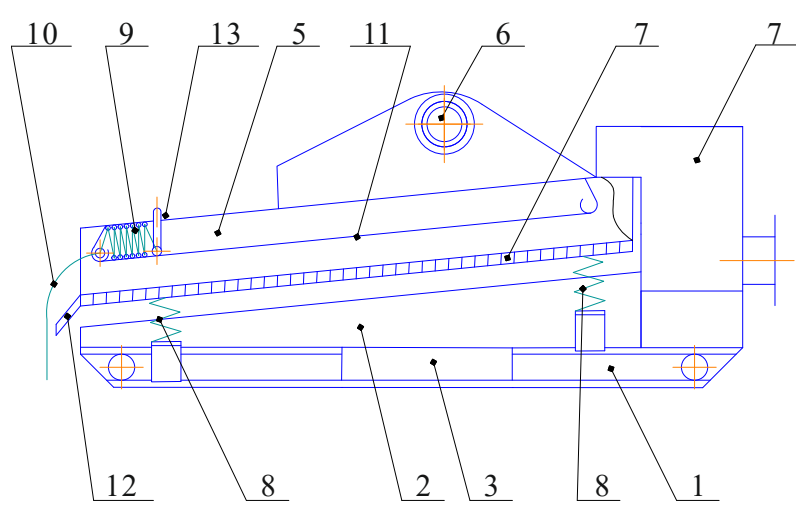

Figure 6. Diagram of a mud screen with a folded protective shield: 1-bottom; 2-tub; 3-draining hole; 4-feed bin; 5-vibrating frame; 6-vibrator; 7 -net; 8-shock absorbers; 9-protective shield; 10 -shield extension; 11 -sliding bars; 12 - folding-back part

To improve operating and environmental characteristics of the equipment for fine cleaning of the mud, i.e. mud desilters, a modernized mud desilter has been designed (Liakh et al., 2010). 
Design of the tool makes it possible to reduce the amount of similar facilities which in its turn will not only reduce penetration of hazardous substances into the environment during fine cleaning of the mud but also cut its production expenses. From the viewpoint of environmental marketing, use of a modernized mud desilter reduces material consumption and improves environmental performance of the equipment.

Modernization of separate elements of a pumpingcirculatory system allows improving environmental safety indices however, a system approach is more effective as it takes into account both modernizing separate equipment and its rational positioning, selection of the material it is made of etc. That is why it is necessary to design a new scheme of a pumping-circulatory system that will take into account and correct certain faults of the available circulatory systems.

\subsection{Design of a modernized pumping-circulatory system}

To solve the problem of environmental safety improvement and the effectiveness of washing the wells being drilled, a modernized scheme of a pumping-circulatory system of a drilling rig has been designed (Fig. 7).

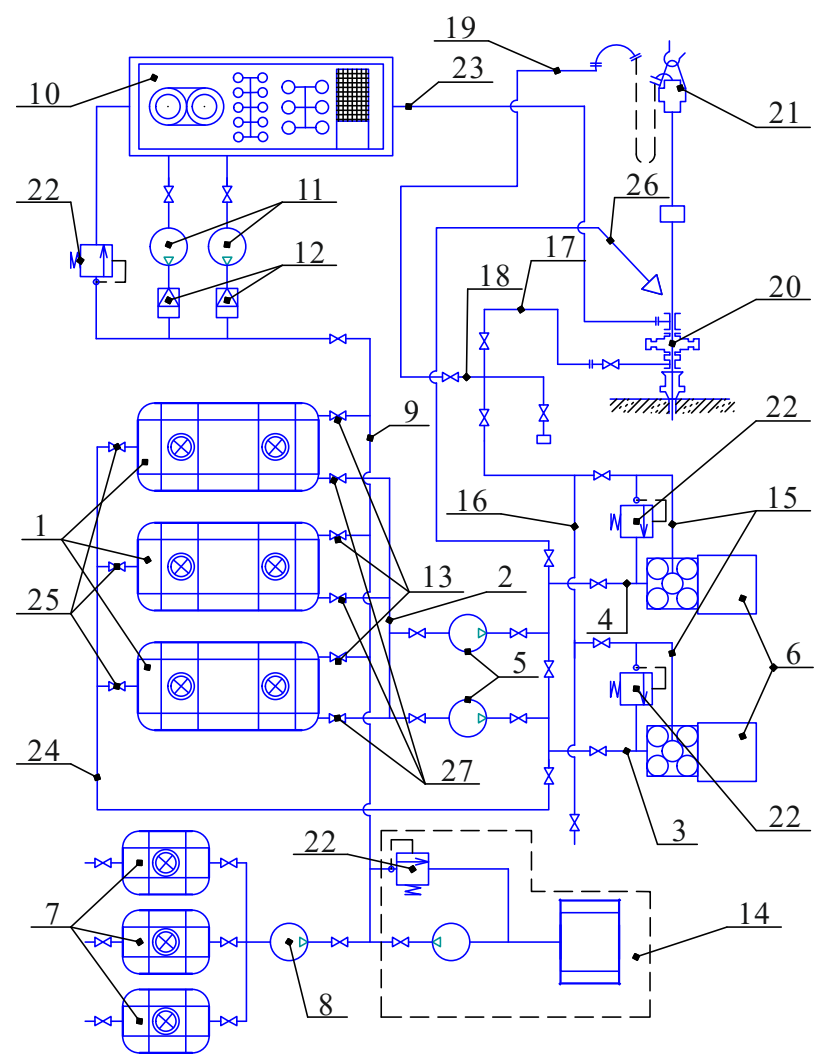

Figure 7. Diagram of a modernized pumping-circulatory system of a drilling rig

Features of the proposed scheme are as follows: receiving tanks and tanks with chemical reagents are airtight being made of elastic material; they can be folded compactly in order to ease their transportation and assembling/disassembling. Sections of the intake line are equipped with aligned drilling mud pumps and pipe fitting to mix the mud in closed receiving tanks made of elastic material to perform borehole makeup if it is ne- cessary. Channel circulation line is closed; it consists of elastic pipelines. To provide proper mud circulation, the line is equipped with the aligned mud pumps from a cleaning unit and from the tanks with chemical reagents To distribute and regulate mud flows, sections of intake and discharge lines as well as sections of a channelcirculatory line are equipped with optimum set and positioning of isolation valves, back valves, and protective switch units.

Modernized pumping-circulatory system consists of air-tight receiving tanks 1 made of elastic material. They are connected by means of sections 2,3,4 of the intake line and through drilling mud pumps 5 with drilling pumps 6 and tanks 7 with chemical reagents connected through drilling mud pump 8 with section 9 of a channelcirculatory line. That line is connected to a cleaning unit 10 through drilling mud pumps 11 and back valves 12 ; it is also connected with receiving tanks 1 through gates 13. A drilling mud preparation unit 14 is also connected with section 9 of a channel-circulatory line. From the drilling pipes 6 , sections $15,16,17$, and 18 of a discharge line are joined successively and in parallel to each other and section 17 by means of the other end to equipment 20 of the mouth of the well, and section 18 is connected to standpipe 19 with rotary swivel 21 .

Section 23 of a channel circulatory line is mounted from equipment 20 of a well mouth to a cleaning unit. Safety switch units 22 are installed in every section of the line where overpressure is likely to occur. Drilling mud pumps 5 are also connected through respective isolation valves 27 to receiving tanks 1 ; gates of other sections of the intake line are connected with section 24 and gates 25 mounted on fitting pipes of receiving tanks 1 and in reverse direction through section 26 to the well mouth equipment 20.

Pumping-circulatory system of a drilling rig operates as follows. The mud is delivered to drilling pumps 6 from receiving tanks 1 made of air-tight elastic material through sections 2,3,4 of the intake line and, in terms of open gates 27, from the tanks and other corresponding gates located at the above-mentioned sections with the help of drilling mud pumps 5 . In this case, drilling mud pumps acts as supercharger pumps. If it is necessary, both drilling mud pumps 5 and drilling pumps 6 may operate one at a time or by two in parallel. Drilling pumps 6 deliver the mud through sections 15 and 18 of the intake line to the standpipe 19 and through the rotary swivel 21 with the drilling string into the well. The mud, saturated with drilled-out rock, goes out of the well through equipment 20 of the well mouth, and enters cleaning unit 10 through section 23 of a channel-circulatory line.

From the cleaning unit 10 , with the help of one or two drilling mud pumps 11 , the mud is delivered into receiving tanks 1 through back valves 12 and section 9 of a channel-circulatory line in terms of open gates 13 . When reverse circulation is necessary, the mud is delivered into the well by drilling pumps 6 through sections 15,17 of intake line and equipment 20 of the mouth. The well makeup by the mud is performed through section 26 and equipment 20 involving one of drilling mud pumps 5 .

In case of emergency - mud overpressure on one of the sections - corresponding switch unit 22 will come 
into action to bleed off the pressure. To process the mud with chemical reagents from tanks 7 , drilling mud pump 8 is used to deliver chemical substance through section 9 into one or several receiving tanks 1 with open gate. When it is required, the mud is prepared in mud preparation unit 14 and is delivered by means of drilling mud pump to receiving tank 1 through section 9 of a channelcirculatory line. To mix the mud in one of the receiving tanks 1 , one of the drilling mud pumps 5 is used which delivers the mud from tank 1 through section 24 and open gate 25 respectively providing closed circulation through the tank where the mud is being mixed.

\section{DISCUSSION}

Maximum air-tight pumping-circulatory system of a drilling rig has been designed on the basis of the results of the studies. In that context, transportability, ease of assembling, and ease of the system operation were taken into account.

Great attention was paid to designing the tanks for mud and chemical reagents storage. During the system exploitation process, when the mud will not be able to circulate, the heavier particles may precipitate preventing the fluid from its movement. Thus, the system must have such a piping so that its separate sections could be washed by the mud drilling pump.

The proposed pumping-circulatory system prevents and reduces efficiently the evaporation of the mud containing hazardous substances at different sections of a pumping-circulatory system during various technological operations while drilling. Changes in mud parameters take place in terms of a closed pumping-circulatory system that also prevents hazardous substances from penetrating into the environment. The proposed pumping-circulatory system of a drilling rig is easy to transport. When folded, the tanks are compact; they do not take much space and do not require special vehicles for their transportation. The tanks are quite light-weighted and convenient for loading/unloading and assembling/disassembling operations. Besides, they are made of elastic material and may be used for oil product collecting in case of uncontrolled oil showings and other emergency situations.

When all the above-mentioned and other technological operations connected with the proposed pumpingcirculatory system are performed, it reduces greatly environmental pollutions at the expense of maximum air-tightness of all the system sections and rational positioning of all its components.

Further research should involve studies of new environmentally safe mud compositions that would meet all the technological requirements. It is also very important to improve professional level of drilling rig personnel in terms of environmental awareness as well as to take into consideration current regulations concerning the safest operation modes during oil and gas wells construction.

\section{CONCLUSIONS}

Possible risks during oil and gas wells construction have been evaluated in order to define the most dangerous parts of the equipment and technological processes during oil and gas wells construction.
It has been determined that maximum risk values $R_{z}$ are observed during round trips and in terms of mud availability in a cleaning unit and channel system $\left(R_{z}=0.99\right)$. HQ during round trips and during mud circulation through channel system is more than 1 which cannot be acceptable for drilling personnel.

Certain ways to improve the equipment have been outlined; modernized scheme of a pumping-circulatory system has been proposed. The design of the system allows making its elements maximum air-tight to prevent penetration of the mud hazardous substances into the environment, to minimize expenses for transportation, assembling, operating, servicing, dismantling as well as creating safe work conditions for the personnel. The system makes it possible to perform all the required technological processes during well construction. The considered ways of environmental safety improvement may be applied both to better environmental safety and compliance at different stages of oil-and-gas industry life cycle and for different industrial branches.

\section{ACKNOWLEDGEMENTS}

Authors of the paper express their gratitude to the Rector of Ivano-Frankivsk National Technical University of Oil and Gas, Academician of the National Academy of Sciences of Ukraine, Doctor of Technical Sciences, Professor Yevstakhii Ivanovych Kryzhanivskyi for his assistance in the research.

\section{REFERENCES}

Alymov, V., \& Tarasova, N. (2004). Tekhnogennyy risk: analiz i otsenka. Moskva: Nedra.

Arakelyan, E., Lyskova, Z., \& Korchakov, V. (1997). Sistema zamknutogo obratnogo vodosnabzheniya burovoy skvazhiny. Patent No. 2084611, Rossiyskaya Federatsiya.

Fedorovych, Ya., Kryzhanivskyi, Ye., Korop, I., \& Liakh, M. (2008). Mobilna burova ustanovka. Patent No. 35712, Ukraina.

Kurhanskyi, V. (2006). Do pytannia zabrudnennia otochuiuchoho seredovyshcha $\mathrm{v}$ protsesi burinnia naftovykh i hazovykh sverdlovyn. Visnyk Kyivskoho Natsionalnoho Universytetu imeni Tarasa Shevchenka. Heolohiia, (38-39), 7-9.

Liakh, M., Vakaliuk, V., Yatsyshyn, T., Solonychnyi, Ya., Liakh, Yu., \& Vilchyk, O. (2010). Hidrotsyklon. Patent No. 89267, Ukraina.

MOZ. (2007). Nakaz "Pro zatverdzhennia metodychnykh rekomendatsii "Otsinka ryzyku dlia zdorovia naselennia vid zabrudnennia atmosfernoho povitria”. Kyiv: Ministerstvo okhorony zdorovia Ukrainy.

Podavalov, Y. (2010). Ekologiya neftegazovogo proizvodstva. Moskva: Infra-Inzheneriya.

Savyk, V., Pedenko, Yu., Liakh, M., Sieryi, V., Tymoshenko, V., \& Luzhanytsia, O. (2009). Skhema obviazky tsyrkuliatsiinoi systemy pry burinni z promyvanniam sverdlovyny pinoiu. Patent No. 42464, Ukraina.

Shkitsa, L., \& Yatsyshyn, T. (2012). Stan ekolohichnoi bezpeky terytorii burovoi ustanovky $\mathrm{v}$ zalezhnosti vid intensyvnosti vyparovuvannia burovoho rozchynu. Modeliuvannia ta Informatsiini Tekhnolohii, (65), 10-16.

Shkitsa, L., \& Yatsyshyn, T. (2013). Computer-aided chart of ecological safety evaluation of atmospheric pollution by mud steams. Scientific Bulletin of North University of Baja Mare. Series D. Mining Mineral Processing Non-Ferrous Metallurgy Geology and Environmental Engineering, XXVII(1), 131-138. 
Shkitsa, L., Yatsyshyn, T., Liakh, M., \& Fedoliak, N. (2013). Vibrosyto dlia ochyshchennia burovoho rozchynu. Patent No. 101928, Ukraina.

Shkitsa, L., Yatsyshyn, T., Popov, A., \& Artemchuk, V. (2013). Prognozirovaniye rasprostraneniya zagryaznyayushchikh veshchestv $\mathrm{v}$ atmosfere na territorii burovoy ustanovki. Neftyanoye Khazyaystvo, (11), 136-140.

Shkitsa, L., Yatsyshyn, T., Lyakh, M., \& Sydorenko, O. (2016). Means of atmospheric air pollution reduction during drilling wells. IOP Conference Series: Materials Science and Engineering, (144), 012009. https://doi.org/10.1088/1757-899x/144/1/012009

Shvydkyi, O. (2010). Pro kompleksnyi pidkhid do modernizatsii nasosno-tsyrkuliatsiinoi systemy burovoi ustanovky.
Zbirnyk Naukovykh prats NAK "Naftohaz Ukrainy”. Problemy Naftohazovoi Promyslovosti, (8), 197-200.

Steinsvag, K., Galea, K.S., Krüger, K., \& Peikli, V. (2011). Effect of drilling fluid systems and temperature on oil mist and vapour levels generated from shale shaker. The Annals of Occupational Hygiene, 55(4), 347-356. https://doi.org/10.1093/annhyg/meq097

Tishchenko, N. (1991). Okhrana atmosfernogo vozdukha. Raschet soderzhaniya vrednykh veshchestv $i$ ikh raspredeleniye $v$ vozdukhe. Moskva: Khimiya.

Yatsyshyn, T. (2012). Ohliad matematychnykh modelei protsesu vyparovuvannia. Modeliuvannia ta Informatsiini Tekhnolohii, (66), 18-30.

\section{ШЛЯХИ ПІДИЩЕННЯ ЕКОЛОГІЧНОЇ БЕЗПЕКИ НАСОСНО-ЦИРКУЛЯЦЙНОЇ СИСТЕМИ БУРОВОЇ УСТАНОВКИ}

\section{Л. Шкіца, Т. Яцишин, М. Лях, О. Сидоренко}

Мета. Вдосконалення насосно-циркуляційної системи бурової установки для покращення показників екологічної безпеки, надійності та зручності при спорудженні нафтогазових свердловин.

Методика. Використано методи системного аналізу умов і досвіду експлуатації різноманітних конструктивних особливостей пристроїв та обладнання насосно-циркуляційних систем для промивання свердловин буровими розчинами. Проведено комп'ютерне моделювання оцінки ризиків при роботі насосно-циркуляційної системи, а також оцінювання й узагальнення теоретичних та експериментальних даних для можливості створення екологічно безпечної насосно-циркуляційної системи.

Результати. Запропоновано вдосконалену схему насосно-циркуляційної системи, особливостями якої є виконання складових з еластичного матеріалу (наприклад, гумовотканинного), який забезпечує герметичність та ізоляцію шкідливих речовин від потрапляння в навколишнє середовище. Модернізована насосно-циркуляційна система, з точки зору досягнення ефективних виробничих результатів, задовольняє наступні вимоги: оперативно переналагоджується на метод буріння, який відповідає конкретним умовам; має мінімальні витрати часу на перевезення до місця роботи, монтаж і демонтаж; $є$ компактною для підвищення маневреності; має комфортні та безпечні умови праці для обслуговуючого персоналу; володіє мінімальною схильністю до ушкоджень.

Наукова новизна. В роботі продемонстровано підхід для підвищення рівня екологічної безпеки, охорони праці та якості виробничих процесів на прикладі насосно-циркуляційної системи, який базується на поетапному дослідженні різних ділянок обладнання, технологічних процесів і впливу речовин, що їх супроводжують. Це дало можливість встановити напрями вдосконалення обладнання: підібрати найбільш відповідні матеріали для виконання окремих одиниць обладнання, визначити їх розташування та забезпечити необхідні режими роботи. Такий підхід для підвищення рівня екологічної безпеки доцільно використовувати й на інших етапах життєвого циклу нафтогазової галузі.

Практична значимість. Запропонована насосно-циркуляційна система потребує мінімальних фінансових витрат на транспортування, монтаж, експлуатацію, обслуговування й демонтаж.

Ключові слова: насосно-ииркуляиійна система, екологічна безпека, нафтогазові свердловини, спорудження свердловин, гумово-тканинні резервуари, буровий розчин

\section{ПУТИ ПОВЫШЕНИЯ ЭКОЛОГИЧЕСКОЙ БЕЗОПАСНОСТИ НАСОСНО-ЦИРКУЛЯЦИОННОЙ СИСТЕМЫ БУРОВОЙ УСТАНОВКИ}

\section{Л. Шкица, Т. Яцишин, М. Лях, О. Сидоренко}

Цель. Совершенствование насосно-циркуляционной системы буровой установки для улучшения показателей экологической безопасности, надежности и удобства при сооружении нефтегазовых скважин.

Методика. Использованы методы системного анализа условий и опыта эксплуатации различных конструктивных особенностей устройств и оборудования насосно-циркуляционных систем для промывки скважин буровыми растворами. Проведено компьютерное моделирование оценки рисков при работе насосно-циркуляционной системы, а также оценка и обобщение теоретических и экспериментальных данных для возможности создания экологически безопасной насосно-циркуляционной системы.

Результаты. Предложена усовершенствованная схема насосно-циркуляционной системы, особенностями которой является выполнение составляющих из эластичного материала (например, резинотканевого), обеспечивающего герметичность и изоляцию вредных веществ от попадания в окружающую среду. Модернизированная насосно-циркуляционная система, с точки зрения достижения эффективных производственных результатов, удовлетворяет следующим требованиям: оперативно переналаживается на метод бурения, который соответствует конкретным условиям; имеет минимальные затраты времени на перевозку до места работы, монтаж и демонтаж; является компактной для повышения маневренности; имеет комфортные и безопасные условия труда для обслуживающего персонала; обладает минимальной склонностью к повреждениям. 
Научная новизна. В работе продемонстрирован подход для повышения уровня экологической безопасности, охраны труда и качества производственных процессов на примере насосно-циркуляционной системы, основанный на поэтапном исследовании различных участков оборудования, технологических процессов и влиянии сопровождающих веществ. Это позволило установить направления совершенствования оборудования: подобрать наиболее подходящие материалы для выполнения отдельных единиц оборудования, определить их расположение и обеспечить необходимые режимы работы. Такой подход для повышения уровня экологической безопасности целесообразно использовать и на других этапах жизненного цикла нефтегазовой отрасли.

Практическая значимость. Предложенная насосно-циркуляционная система требует минимальных финансовых затрат на транспортировку, монтаж, эксплуатацию, обслуживание и демонтаж.

Ключевые слова: насосно-циркуляционная система, экологическая безопасность, нефтегазовые скважины, бурение скважин, резиново-тканевые резервуары, буровой раствор

\section{ARTICLE INFO}

Received: 19 April 2018

Accepted: 22 August 2018

Available online: 1 September 2018

\section{ABOUT AUTHORS}

Lesia Shkitsa, Doctor of Technical Sciences, Head of the Engineering and Computer Graphics Department, IvanoFrankivsk National Technical University of Oil and Gas, 15 Karpatska St, 76019, Ivano-Frankivsk, Ukraine. E-mail: lshkitsa@nung.edu.ua

Teodoziia Yatsyshyn, Candidate of Technical Sciences, Associate Professor of the Department of Ecology, IvanoFrankivsk National Technical University of Oil and Gas, 15 Karpatska St, 76019, Ivano-Frankivsk, Ukraine. E-mail: yatsyshyn.t@gmail.com

Mykhailo Liakh, Candidate of Technical Sciences, Professor of the Oil and Gas Equipment Department, IvanoFrankivsk National Technical University of Oil and Gas, 15 Karpatska St, 76019, Ivano-Frankivsk, Ukraine. E-mail: mm.lyakh@gmail.com

Olha Sydorenko, Engineer of the Ecological Researches Laboratory, Scientific-Research and Design Institute PJSC "Ukrnafta", 2 Pivnichnyi Bulvar St, 76019, Ivano-Frankivsk, Ukraine. E-mail: sydorolya1@gmail.com 